\title{
Review
}

\section{Nutrigenomics, Vitamin D and Cancer Prevention}

\author{
Cindy D. Davis John A. Milner \\ Nutritional Science Research Group, National Cancer Institute, Rockville, Md., USA
}

\author{
Key Words \\ Vitamin D $\cdot$ Cancer prevention $\cdot$ Vitamin D receptor $\cdot$ Nutrigenomics $\cdot$ Biomarkers • \\ Polymorphisms
}

\begin{abstract}
Although there is growing epidemiological, preclinical and clinical evidence suggesting that low vitamin D intake, exposure and/or status is associated with an increased risk of various types of cancer, the optimum amount needed remains controversial. Furthermore, there is evidence that a U- or J-shaped response curve exist between $25(\mathrm{OH}) \mathrm{D}$ and certain cancers. Increasing information about the impact of genetic variation, especially polymorphisms that influence absorption, transport, metabolism and associated molecular targets, should help clarify inconsistencies in the data regarding vitamin D's effect on cancer risk. Rather than focusing on the main effects of a few variants of these genes alone, future studies need to consider gene-nutrient or environmental interactions. Nutrigenomics should clarify who might benefit and be placed at risk because of vitamin D exposure.

Copyright $\odot 2011$ S. Karger AG, Basel
\end{abstract}

There is a limited number of unfortified foods that naturally contain vitamin D. Fatty fish like salmon, tuna and mackerel are the best sources. Smaller amounts occur in liver, cheese, egg yolks and mushrooms. A number of foods are fortified with vitamin D, including milk and milk products, orange juice, breakfast cereals and bars, grain products and pastas, infant formulas and margarines. Dietary intake from all sources for men and women aged 51-70 in the United States have been estimated to be $352 \pm 16$ and $404 \pm 40$ IU/day, respectively [1].

Vitamin D can be synthesized in the skin following exposure to UVB-radiation in the range of 290-315 $\mathrm{nm}$. Skin color influences markedly the amount of vitamin D that can be 
synthesized [2]. Regardless of whether vitamin D comes from the skin or the diet, vitamin D is transported in the circulation bound to the vitamin D-binding protein [3]. Vitamin D is rapidly converted to the more stable metabolite 25-hydroxy-vitamin $\mathrm{D}[25(\mathrm{OH}) \mathrm{D}]$ in the liver. The active form of vitamin $\mathrm{D}$ in the body is 1,25 -dihydroxyvitamin $\mathrm{D}\left[1,25(\mathrm{OH})_{2} \mathrm{D}\right]$ which is synthesized primarily in the kidney by the enzyme $25(\mathrm{OH})$ vitamin $\mathrm{D}-1-\alpha$-hydroxylase (CYP27B1). Serum 25(OH)D is the primary circulating form of vitamin D, has a half-life that is considerably longer than that of $1,25(\mathrm{OH})_{2} \mathrm{D}(15$ days vs. $15 \mathrm{~h}$ ) [4], and has been correlated with total vitamin $\mathrm{D}$ exposure from both endogenous production and the diet [5-8].

More recently, multiple autocrine/paracrine functions of vitamin D have been demonstrated which are manifested by local production of $1,25(\mathrm{OH})_{2} \mathrm{D}$. Many tissues in addition to the kidney possess the enzyme CYP27 1 and therefore can synthesize $1,25(\mathrm{OH})_{2} \mathrm{D}$ from circulating $25(\mathrm{OH}) \mathrm{D}$. The autocrine synthesis of $1,25(\mathrm{OH})_{2} \mathrm{D}$ in organs, such as the prostate, colon, breast, and pancreas is a mechanism whereby vitamin $\mathrm{D} /$ sunlight influences the development of cancer at these sites [9]. Thus, factors influencing circulating 25(OH)D or transport across membranes can influence autocrine function.

\section{Vitamin D and Cancer Prevention}

The first human evidence to suggest a relationship between vitamin D and cancer prevention came from ecologic or geographic studies which suggested increased sunlight (UVB) exposure or populations living in lower latitudes had a lower incidence of colon cancer [10], and later a reduced risk of prostate cancer [11]. Because ultraviolet radiation can lead to vitamin $\mathrm{D}$ formation in the skin, this led to the hypothesis that vitamin $\mathrm{D}$ or one of its metabolites $\left[25(\mathrm{OH}) \mathrm{D}\right.$ or $\left.1,25(\mathrm{OH})_{2} \mathrm{D}\right]$ may be protective against cancer. Since DNA damage is known to result from excessive sunlight exposure, foods and dietary supplements have emerged as an alternative strategy for optimizing one's vitamin D status.

A diversity of scientific literature, including in vitro, animal, ecologic and epidemiologic studies supports a role for vitamin D in decreasing colorectal cancer incidence [12-17]. In a recent meta-analysis of studies that examined serum $25(\mathrm{OH}) \mathrm{D}$ levels prospectively in relation to colorectal cancer, individuals with $25(\mathrm{OH}) \mathrm{D}$ concentrations $\geq 82 \mathrm{nmol} / \mathrm{l}$ had a $50 \%$ lower incidence of colorectal cancer than those with $25(\mathrm{OH}) \mathrm{D} \leq 30 \mathrm{nmol} / \mathrm{l}$ [17].

Despite abundant experimental evidence in support of an inverse association between vitamin $\mathrm{D}$ status and breast cancer risk, the available epidemiologic evidence provides, at best, limited support for such an association [18]. Similarly, the association between vitamin D status and prostate cancer risk are less compelling than those for colorectal cancer, suggesting that not all tissues respond identically [19]. A recent meta-analysis of observational studies of the summary relative risk for a $10 \mathrm{ng} / \mathrm{ml}$ increase in $25(\mathrm{OH}) \mathrm{D}$ was 0.85 for colorectal cancer (2,630 cases in 9 studies, range $0.79-0.91), 0.89$ for breast cancer (6,175 cases in 10 studies, range $0.81-0.98)$ and 0.99 for prostate cancer (3,956 cases in 11 studies, range 0.95-1.03) [20]. A very extensive critical analysis of the epidemiological data on vitamin $\mathrm{D}$ and cancer by the World Health organization [21] concluded that (1) observational studies link low 25(OH)D levels with colorectal adenoma and cancer; (2) vitamin D supplementation did not change the risk of overall cancer incidence in two intervention studies, and (3) therefore, the causal relationship between vitamin $\mathrm{D}$ and cancer is still unclear and additional randomized clinical trials are needed; and until definitive evidence is obtained, a restrictive attitude should be applied with regard to aggressive vitamin D supplementation or increased UVB exposure.

Several hypotheses have surfaced to explain the inconsistencies in the literature about vitamin D and cancer [19]. It is possible that vitamin D is more effective for cancer progression than for retarding the incidence. Furthermore, the risk associated with low vitamin $\mathrm{D}$ 
status may be conferred early in life, and thus studies of circulating levels of $25(\mathrm{OH}) \mathrm{D}$ or dietary intake in adulthood may not be the most relevant time period of exposure. Finally, the response between $25(\mathrm{OH}) \mathrm{D}$ and cancer risk may occur at extremely low levels of circulating $25(\mathrm{OH}) \mathrm{D}$ [19]. Undeniably, additional studies are needed to determine the optimal level of $25(\mathrm{OH}) \mathrm{D}$, the length of time required to observe an effect, and when during life that maximum benefit may occur [19].

Concerning evidence has emerged that some individuals may be adversely affected by elevated $25(\mathrm{OH}) \mathrm{D}$ concentrations, with respect to risk of cancer of the prostate [22, 23], breast [24], pancreas $[25,26]$ and esophagus $[27,28]$. In some cases a U- or J-shaped association has been suggested [29]. Since a similar relationship has been observed with other food components including selenium, folate, and $\beta$-carotene, it is possible that vitamin $\mathrm{D}$ would produce similar effects. The balance between benefit and harm likely depends on the time and duration of exposure, tissue specificity, lifestyle factors and genetic polymorphisms.

\section{Nutrigenetic Studies}

The most frequently studied gene that influences the vitamin $\mathrm{D}$ status is the vitamin $\mathrm{D}$ receptor (VDR). VDR is an intracellular hormone receptor that specifically binds $1,25(\mathrm{OH})_{2} \mathrm{D}$ and interacts with vitamin $\mathrm{D}$ response elements of target genes to produce a variety of biologic effects. VDR protein could be associated with either an increased susceptibility to cancer or to a more aggressive disease [30]. More than 470 single-nucleotide polymorphisms (SNPs) have been discovered on the human VDR gene, yet most have low allele frequency [31]. The most frequently studied single nucleotide polymorphisms are the restriction fragment length polymorphisms FokI (rs2228570) and BsmI (rs1544410), as defined by the restriction enzymes FokI and BsmI, respectively. Several large studies reported ethnic variation in the occurrence of $V D R$ gene polymorphisms [32, 33]. The $f$ allele of FokI occurs less frequently in Africans as compared to Caucasians and Asians, whereas the frequency of the $B s m I$ B allele is much lower in the Asian population compared to other populations (Fok $1 f$ : Caucasians 34\%, Asians 51\%, Africans 24\%; BsmI B: Caucasians 42\%, Asians 7\%, Africans $36 \%)[32,33]$.

The FokI restriction fragment length polymorphism is located in the coding region of the VDR gene and the $f$ allele results in the production of a VDR protein that is three amino acids longer and functionally less effective. In transient transfection assays with a vitamin D-responsive reporter gene, the shorter VDR protein displayed higher biological activity than the longer one [34]. The wild-type protein FF interacts more efficiently with the transcription factor TFIIB increasing transactivation by the VDR compared to the ff protein by 1.7-fold [35]. Thus, the cellular consequences of the $f f$ genotype are similar to that of lower vitamin D status [36]. In fact, serum $25(\mathrm{OH}) \mathrm{D}$ concentrations are lower among individuals with the $f f$ versus FF genotype ( 64 vs. $100 \mathrm{nmol} / \mathrm{l}$, respectively; $\mathrm{p}=0.005$ ) [36]. A meta-analysis of the relationship between FokI polymorphisms and cancer found a significant $30 \%$ increase in skin cancer risk and 14\% increase in breast cancer risk with FokI ff compared with FF genotype [30]. In contrast, no consistent relationship between the FokI polymorphism and colorectal cancer was observed [30]. However, Slattery et al. [37] reported that BMI, energy intake, energy expenditure may influence the relationship between VDR FokI genotype and colorectal cancer risk. The $f f$ genotype was associated with a $>2$-fold greater risk of colon cancer for obese people ( $\mathrm{OR}=2.62 .95 \% \mathrm{CI}$ : $1.15-5.99)$ and with a $>3$-fold greater risk of colon cancer in people who were not physically active (OR $=3.46,95 \% \mathrm{CI} 1.58-7.58)$ [37]. Other food components may influence the genetic link since studies from China reveal the $f f$ genotype was associated with a 2.5 -fold increased risk among those with either low 
calcium or low fat intake [38]. The ability of food components to influence the response and biological consequences of vitamin $\mathrm{D}$ deserve additional attention.

The BsmI polymorphism is intronic and located at the $3^{\prime}$ end of the gene. This polymorphism has not been found to alter the amount, structure or function of the VDR protein produced; however, it is in linkage disequilibrium with the a poly (A) microsatellite repeat in the $3^{\prime}$ untranslated region [39]. Linkage disequilibrium describes the co-occurrence of alleles of adjacent polymorphism with the each other. The poly(A) microsatellite repeat contains a variable number of 12 or more alleles; the population distribution of the number of these alleles is bimodal and individuals can be classified as having short (A13-A17) or long (A18A24) nucleotides. The poly(A) sequence is thought to be important in post-transcriptional control of gene expression [40] by altering mRNA stability of the interaction of the mRNA with the translational apparatus, which would result in greater mRNA instability with the long genotype [40]. Meta-analysis of studies investigating the relationship between the BsmI polymorphism and prostate cancer risk found a significant $17 \%$ reduction in prostate cancer risk for carriers of the $B s m \mathrm{I} B b$ compared with $b b$ genotype [30].

Nutrigenetic studies have revealed that a number of other genes involved in vitamin D metabolism can influence the response. CYP27B1, which encodes for the $1 \alpha$-hydroxylase which hydroxylates $25(\mathrm{OH}) \mathrm{D}$ to $1,25(\mathrm{OH})_{2} \mathrm{D}$, has been examined as a variable. Although 4 nonsynonymous SNPs have been identified, all are relatively rare [39]. To date, there is no evidence that these SNPS affect gene function or disease risk. However, CYP24A1 which initiates the degradation of $1,25(\mathrm{OH})_{2} \mathrm{D}$ by hydroxylation of the side chain can have functional SNPs in the promoter that lower expression of the protein [39]. Several variants in CYP24A1 have been correlated with increased colon cancer risk in a population-based case-control study involving 1,600 cases and 1,949 controls [41].

The $G c$ gene encodes for a vitamin D-binding protein (DBP). Six nonsynonymouse SNPS have been identified; two with relatively high frequency (rs7041 and rs4588). Recent studies have shown that allelic variation in the Gc gene is associated with DBP and serum $25(\mathrm{OH}) \mathrm{D}$ concentrations $[42,43]$. Moreover, in genome-wide association studies, a SNP in the $G c$ gene ( $r s 2282679$ ) which is in linkage disequilibrium with $r s 7041$ and $r s 1155563$ was also associated with lower $25(\mathrm{OH}) \mathrm{D}$ concentrations [44]. The relationship between Gc SNPs and cancer risk has not been explored adequately.

The aforementioned studies serve as proof-of-principle that genetic polymorphisms can modify the relationship between vitamin $\mathrm{D}$ status and cancer risk. Future studies need to consider the interaction of gene variants and lifestyle/environmental factors that influence risk. To date, the majority of studies have been correlative and thus additional basic preclinical and clinical nutrition intervention studies are warranted.

\section{Transcriptomic Effects of 1,25(OH $)_{2}$ D}

$1,25(\mathrm{OH})_{2} \mathrm{D}$ is thought to act locally through multiple mechanisms [45]. A rapid response may occur through a plasma membrane receptor and second messengers involved in regulating various cell activities, including cell cycle control which is sometimes referred to as a nongenomic mechanism. As mentioned previously, genomic effects are mediated via binding of $1,25(\mathrm{OH})_{2} \mathrm{D}$ to the nuclear VDR. The VDR then binds to target DNA sequences as a heterodimer with the retinoid $\mathrm{X}$ receptor, recruiting a series of coactivators which results in the induction of target gene expression (fig. 1). Vitamin D response elements (VDREs) are located on more than 200 genes and can influence a number of biological processes including cell proliferation, differentiation, apoptosis, growth factor signaling, inflammation and immunomodulation [40]. 


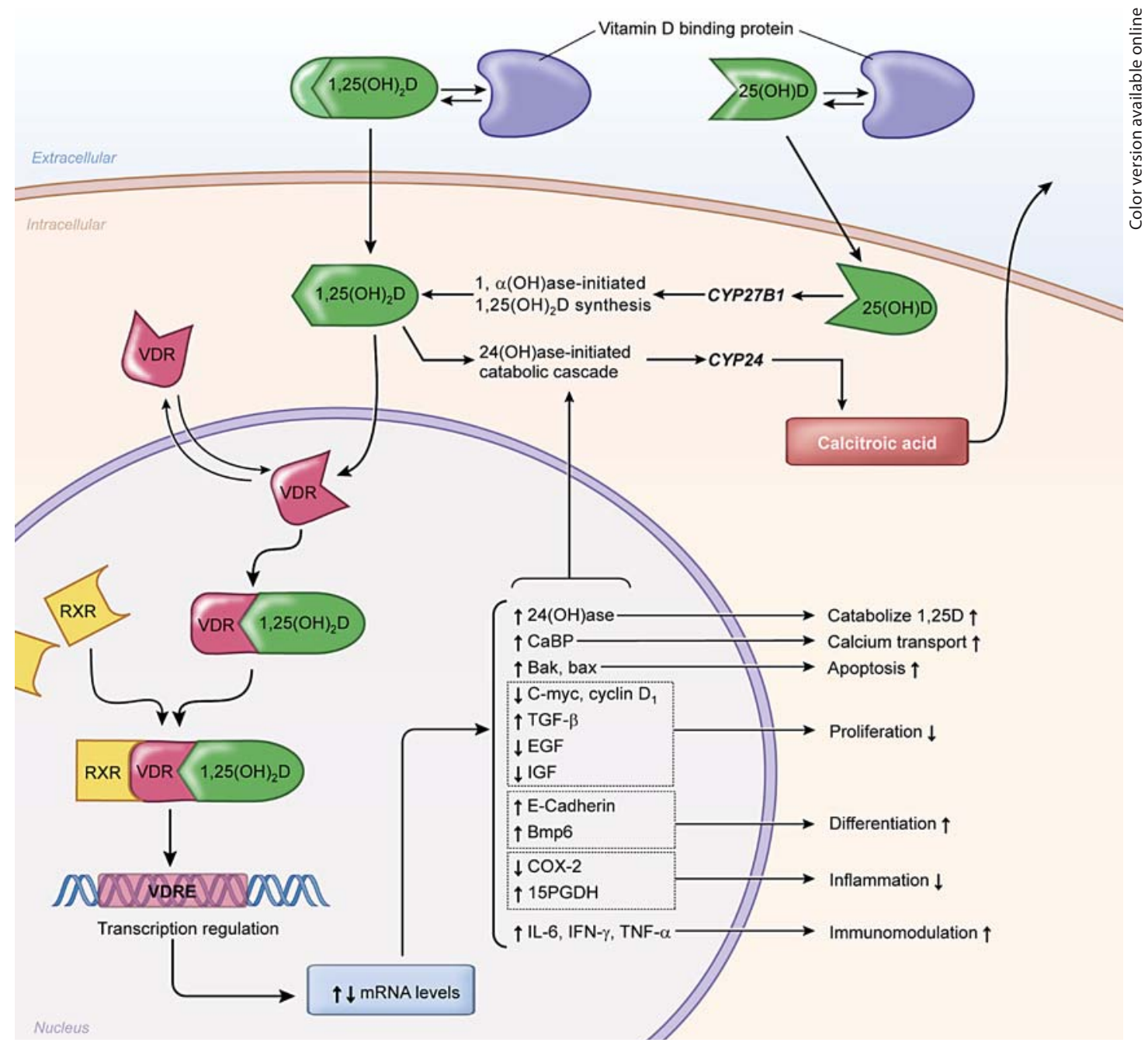

Fig. 1. Proposed mechanism of action of $1,25(\mathrm{OH})_{2} \mathrm{D}$ in target cells. $1,25(\mathrm{OH})_{2} \mathrm{D}$ binds to the vitamin $\mathrm{D}$ receptor (VDR) and forms a heterodimer with the retinoid X receptor (RXR). This complex binds to the vitamin D response element (VDRE) to induce or repress expression of target genes. Examples of genes with VDREs related to carcinogenesis include those involved in regulating apoptosis, proliferation, differentiation, inflammation and immunomodulation. Modified from McCullough et al. [39].

A number of microarray studies have been performed on different types of cancer cells (prostate, breast, ovarian, colorectal, squamous cell carcinoma and leukemia) to identify key genes that are directly regulated by $1,25(\mathrm{OH})_{2} \mathrm{D}[46]$. Common cellular processes targeted by $1,25(\mathrm{OH})_{2} \mathrm{D}$ include cell cycle progression, apoptosis, cellular adhesion, oxidative stress, immune function and steroid metabolism [46]. The most common regulated gene was CYP24 which showed a large induction in cancer cells treated with $1,25(\mathrm{OH})_{2} \mathrm{D}[46]$. However, when the lists of genes regulated by $1,25(\mathrm{OH})_{2} \mathrm{D}$ in the different microarray studies were compared, only a small set of individual genes were found to be commonly regulated [data summarized in 46]. Collectively these findings demonstrate that $1,25(\mathrm{OH})_{2} \mathrm{D}$ acts in a cell type and tissuespecific manner. For example, $1,25(\mathrm{OH})_{2} \mathrm{D}$ inhibits cell growth of both normal and tumor cells by inhibiting the transition for the $\mathrm{G}_{1}$ to the $S$ phase of the cell cycle [47]. This effect was mediated by increased expression of cyclin A1 in ovarian cancer cells [48], whereas breast cancer cells had increased expression of cyclin D2 [49]. 
Consistent with the strong antiproliferative effects that $1,25(\mathrm{OH})_{2} \mathrm{D}$ has on cells, it also directly regulates the gene encoding the cyclin-dependent kinase inhibitor p21 in U937 monocytic cells [50]. Prostate epithelial growth caused by $1,25(\mathrm{OH})_{2} \mathrm{D}$ is blocked by antisense RNA of siRNA against p21 [51]. However, $1,25(\mathrm{OH})_{2} \mathrm{D}$-treated LNCaP prostate cancer cells have increased p21 protein but not mRNA expression [52]. Consistent with this observation, $1,25(\mathrm{OH})_{2} \mathrm{D}$ treatment increased insulin-like growth factor-binding protein 3 (IGFBP3) gene expression, which then increased prostatic p21 indirectly by suppressing insulin-like growth factor-1 (IGF-1) signaling [53].

Vitamin $\mathrm{D}$ is also known to regulate many genes involved in prostaglandin metabolism. $1,25(\mathrm{OH})_{2} \mathrm{D}$ inhibits COX-2 expression and activity, it inhibits expression of prostaglandin receptors and increases prostaglandin catabolism by increasing expression of 15-prostaglandin dehydrogenase [54]. In combination, these three mechanisms reduce prostaglandin levels and signaling, thereby attenuating the growth-stimulatory effects of prostaglandins in prostate cancer [54]. Furthermore, the combination of $1,25(\mathrm{OH})_{2} \mathrm{D}$ and naproxen (a nonsteroidal anti-inflammatory drug), act synergistically in vitro and more effectively inhibit prostate cancer cell growth in patients based on a slowing of the PSA doubling time than either alone [54]. Overall, a better understanding of the molecular targets for vitamin D should identify more effective strategies for cancer prevention and/or treatment.

For a detailed analysis of the regulatory regions of genes that respond to the VDR, chromatin immunoprecipitation (ChIP) is a powerful technique. The spatiotemporal, $1,25(\mathrm{OH})_{2} \mathrm{D}$ dependent chromatin changes in the gene promoter regions of CYP24, CYP27B1, cyclin C and $p 21$ were studied by ChIP assays with antibodies against acetylated histone 4 , VDR, RXR and RNA polymerase II [55-58]. Promising promoter regions were then screened in silico for putative VDR response elements (VDREs), whose functionality was analyzed sequentially with gel shift, reporter gene and re-ChIP assays. This approach identified four VDREs for both the CYP24 and cyclin C genes, three in the p21 promoter and two in the CYP27b1 gene. However, most of them are simultaneously under the control of other transcription factors, such as p53 in the case of the $p 21$ gene [56], and therefore possess significant basal level of transcription. Therefore, the fold induction of gene expression following $1,25(\mathrm{OH})_{2} \mathrm{D}$ is much less than for the CYP24 gene.

The combination of ChIP assays with hybridization of the resulting chromatin fragments on microarrays, which is also known as ChIP-on-chip analysis, provides an additional step for a larger-scale analysis of VDR target genes [59]. The ChIP-on-chip technology has been applied to the analysis of a number of genes including VDR [60], TRPV6 or the intestinal calcium ion channel gene [61], LRP5 which is a co-regulator of Wnt signaling [62], and RankL which promotes the formation of calcium resorbing osteoclasts [63]. A number of VDR-associated chromatin regions were identified for all of these genes. Moreover, these studies demonstrated that most, if not all, VDR target genes have multiple VDREs. ChIP-onchip technology has also demonstrated that mutant p53 can interact functionally and physically with VDR, is recruited to VDR regulated genes and modulates their expression, and increases the nuclear accumulation of VDR [64]. Thus, p53 status can determine the biological impact of $1,25(\mathrm{OH})_{2} \mathrm{D}$ in tumor cells [64].

\section{Posttranscriptional Regulation of Gene Expression}

MicroRNAs (miRNAs) are small noncoding RNAs that regulate gene expression through translational repression or mRNA degradation. Recent studies have demonstrated that miR125b downregulates VDR expression [65] and upregulates CYP24 expression [66] in tumor cells. Electrophoretic mobility shift assays demonstrated that the over-expression of miR- 
125b significantly decreased the endogenous VDR protein level in MCF-7 cells to $40 \%$ of control [65]. Although $1,25(\mathrm{OH})_{2} \mathrm{D}$ drastically induced CYP24 mRNA expression, the induction was markedly attenuated by the overexpression of miR-125b and the antiproliferative effects of $1,25(\mathrm{OH})_{2} \mathrm{D}$ in MCF-7 cells were significantly abolished by the overexpression of miR-125b [66]. These data suggest that increased expression of miR-125b in cancer cells inhibits the beneficial effects of $1,25(\mathrm{OH})_{2} \mathrm{D}$ both by inhibiting VDR expression and increasing CYP24 expression.

\section{Modifiers of the Biological Response to 1,25(OH $)_{2} \mathrm{D}$}

It is important to realize that the development of cancer can markedly influence vitamin $\mathrm{D}$ metabolism and in a tissue-specific manner. For example, in prostate cancer, there is a decrease in the ability of prostatic CYP27b1 to convert $25(\mathrm{OH}) \mathrm{D}$ to $1,25(\mathrm{OH})_{2} \mathrm{D}[67,68]$. While CYP27b1 is present in normal prostate epithelial cells, its activity is reduced in cells isolated from subjects with benign prostatic hypertrophy and nearly absent in cells from subjects with prostate cancer $[67,68]$. Furthermore, androgens can alter the balance between CYP27B1 and CYP24 [69]. Dihydrotestosterone inhibits $1,25(\mathrm{OH})_{2} \mathrm{D}$-mediated induction of CYP24 and several downstream molecular targets of $1,25(\mathrm{OH})_{2} \mathrm{D}$. Interactions also occur between the androgen receptor and vitamin D receptor signaling [69]. Therefore, with advanced prostate cancer, prostate cells are unable to activate $25(\mathrm{OH}) \mathrm{D}$ to suppress cell division and/or promote differentiation. However, transgenic expression of CYP27b1 restored the growthinhibitory response to $25(\mathrm{OH}) \mathrm{D}$ in $\mathrm{LNCaP}$ prostate cancer cells that normally have low CYP27b1 activity [70]. These effects appear to be tissue specific. While CYP27b1 is present in normal breast tissue, its activity is actually higher in malignant breast tissue [71].

Certain cancer cells also demonstrate decreased expression of the VDR. VDR activity is lost in humans in poorly differentiated colon tumors, rendering them unable to extract circulating $1,25(\mathrm{OH})_{2} \mathrm{D}$ [72]. Serum $25(\mathrm{OH}) \mathrm{D}$ measurements in these late stages may be misleading, as adequacy of exposure would not necessarily confer a benefit in advanced carcinogenesis of the colon or rectum.

It has also been suggested that the enzyme responsible for the degradation of vitamin $\mathrm{D}$ metabolites, CYP24, can also be influenced by cancer. The CYP24 gene was amplified in breast tumors [73] and CYP24 mRNA expression was increased in colorectal cancer as compared to adjacent normal tissue [74]. CYP24 protein is present in the nuclei of normal tissue, increased in aberrant crypt foci (a preneoplastic lesion for colon cancer) and polyps, and shifted to the cytoplasm in tumors and metastatic colon cancer [75]. This suggests that advanced colon cancer cells would have increased degradation of $1,25(\mathrm{OH})_{2} \mathrm{D}$.

Multiple bioactive food components likely influence the response to vitamin D. Calcium, often consumed along with vitamin $\mathrm{D}$ in fortified milk and dietary supplements, tends to reduce renal hydroxylation of $25(\mathrm{OH}) \mathrm{D}$ to $1,25(\mathrm{OH})_{2} \mathrm{D}$ [76]. Unfortunately, the impact of calcium on nonrenal tissues remains largely unexplored. Dietary factors, such as retinol, can also influence binding of $1,25(\mathrm{OH})_{2} \mathrm{D}$ to the VDR because of the heterodimer that is formed between the VDR and RXR [39]. Phytoestrogens stimulate colonic synthesis of $1,25(\mathrm{OH})_{2} \mathrm{D}$ from $25(\mathrm{OH}) \mathrm{D}$ via activation of CYP27B1 $[77,78]$. Similarly, folate leads to a similar activation of CYP27B1 [78] and thus raises interesting issues with the fortification of the food supply that has occurred in the many parts of the world. Calcium, phytoestrogens (e.g. genistein in soy), and folate have been observed to inhibit CYP24A1 activity, and therefore degradation of $1,25(\mathrm{OH})_{2} \mathrm{D}$ [79]. Similarly, genistein works synergistically with $1,25(\mathrm{OH})_{2} \mathrm{D}$ or $25(\mathrm{OH}) \mathrm{D}$ in vitro to inhibit growth of prostate epithelial cells and prostate cancer cells [80], potentially through inhibition of CYP24A1 activity and increased stability of the VDR [81]. 
In humans, total body fat also appears to influence vitamin $\mathrm{D}$ status, presumably by being a storage site or 'sink' for vitamin D [82]. Serum 25(OH)D has been observed to be lower in individuals with a BMI $>30$ in a number of observational studies [83-85]. Moreover, while obese and nonobese individuals have similar skin content of vitamin D precursors, obese individuals have a smaller increase in serum vitamin D following ultraviolet exposure [85]. Likewise, vitamin D esters accumulate in the fat of rats as a function of time [86]. It is unclear whether weight loss would create a safety concern since vitamin D may be liberated from adipose stores [87]. Moreover, obesity has been linked to increased colorectal cancer risk. It is unknown whether the increased risk of colon cancer with obesity is mediated through decreased 25(OH)D levels. Thus, while serum 25(OH)D is a marker of vitamin D exposure, it may also be a marker for other risk factors for colorectal cancer. A recent analysis suggested that a low vitamin D status may explain at least $20 \%$ of the cancer risk attributable to high BMI [88]. There is evidence that baseline $25(\mathrm{OH}) \mathrm{D}$ status is positively correlated with thermic effect of a meal [89] and with body fat loss [90] on a reduced calorie diet. The increasing prevalence of obesity worldwide emphasizes the importance of investigating whether the relationships between $25(\mathrm{OH}) \mathrm{D}$ and $\mathrm{BMI}$ and/or adiposity are simply confounding, if there is a direct relationship, and what the nature of such a relationship may be.

Higher physical activity is linked to higher circulating levels of $25(\mathrm{OH}) \mathrm{D}$; however, it is unclear whether this reflects a direct relationship between physical activity and vitamin D metabolism or whether it is a result of confounding by body fat or sun exposure [91]. Furthermore, both the relationship between vitamin D status and obesity and vitamin D status and physical activity were stronger in Caucasians than in African-Americans [91]. These types of relationships highlight the importance of identifying confounders and modifiers of the biological response to vitamin D, including dietary factors, lifestyle factors such as exercise, and race/ethnicity.

In summary, rather compelling evidence exists that inadequate vitamin D exposures are associated with an increase in cancer risk and/or tumor progression. However, the amount needed to curtail cancer remains elusive and therefore serves as a stimulus for continued investigations. It is already abundantly clear that genetics and nutrient-nutrient interactions can influence the overall response to vitamin $\mathrm{D}$. While additional and widespread food fortification might reduce the risk of some cancers, it may also precipitate issues in others. The increase in cancer risk at some sites and increased overall mortality serve as signals that overzealous intakes are unwise. As the field of nutrigenomics expands, the likelihood of identifying those at risk of inadequate or excessive intake will be possible. At this point, it is prudent to achieve the recommendations by the Food and Nutrition Board of the National Academy of Sciences, namely for individuals between 1 and 70 to consume $600 \mathrm{IU}(15 \mu \mathrm{g})$ per day.

\section{References}

1 Bailey RL, Dodd KW, Goldman JA, Gahche JJ, Dwyer JT, Moshfegh AJ, Sempos CT, Picciano MF: Estimation of total usual calcium and vitamin D intakes in the United States. J Nutr 2010;140:817-822.

2 Armas LA, Dowell S, Akhter M, Duthuluru S, Huerter C, Hollis BW, Lund R, Heaney RP: Ultraviolet-B radiation increases serum 25-hydroxyvitamin D levels: the effect of UVB dose and skin color. J Am Acad Dermatol 2007;57:588-593.

3 Daiger SP, Schanfield MS, Cavalli-Sforza LL: Group-specific component (Gc) proteins bind vitamin D and 25-hydroxyvitamin D. Proc Natl Acad Sci USA 1975;72:2076-2080.

4 Jones G: Pharmacokinetics of vitamin D toxicity. Am J Clin Nutr 2008;88:582S-586S.

5 Talwar SA, Aloia JF, Pollack S, Yeh JK: Dose response to vitamin D supplementation among postmenopausal AfricanAmerican women. Am J Clin Nutr 2007;86:1657-1662.

6 Heaney RP, Davies KM, Chen TC, Holick MF, Barger-Lux MJ: Human serum 25-hydroxycholecalciferol response to extended oral dosing with cholecalciferol. Am J Clin Nutr 2003;77:204-210.

7 Aloia JF, Patel M, Dimaano R, Li-Ng M, Talwar SA, Mikhail M, Pollack S, Yeh JK: Vitamin D intake to attain a desired serum 25-hydroxyvitamin D concentration. Am J Clin Nutr 2008;87:1952-1958. 


\section{Journal of \\ Nutrigenetics \\ Nutrigenomics}

\begin{tabular}{l|l}
\hline J Nutrigenet Nutrigenomics 2011;4:1-11 \\
\hline DOI: 10.1159/000324175 & $\begin{array}{l}\text { @ 2011 S. Karger AG, Basel } \\
\text { www.karger.com/jnn }\end{array}$ \\
Published online: March 23, 2011 &
\end{tabular}

Davis et al.: Nutrigenomics, Vitamin D and Cancer Prevention

-8 Cashman KD, Hill TR, Lucey AJ, Taylor N, Seamans KM, Muldowney S, Fitzgerald AP, Flynn A, Barnes MS, Horigan G, Bonham MP, Duffy EM, Strain JJ, Wallace JM, Kiely M: Estimation of the dietary requirement for vitamin D in healthy adults. Am J Clin Nutr 2008;88:1535-1542.

-9 Schwartz GG, Eads D, Rao A, Cramer SD, Willingham MC, Chen TC, Jamieson DP, Wang L, Burnstein KL, Holick MF, Koumenis C: Pancreatic cancer cells express 25-hydroxyvitamin D-1-(-hydroxylase and their proliferation is inhibited by the prohormone, 25-hydroxyvitamin $\mathrm{D}_{3}$. Carcinogenesis 2004;25:1015-20.

10 Garland CF, Garland FC: Do sunlight and vitamin D reduce the likelihood of colon cancer? Int J Epidemiol 1980;9: $227-231$.

-11 Hanchette CL, Schwartz GG: Geographinc patterns of prostate cancer mortality. Evidence for a protective effect of ultraviolet radiation. Cancer 1992;70:2861-2869.

12 Murillo G, Matusiak D, Benya RV, Mehta RG: Chemopreventive efficacy of 25-hydroxyvitamin $\mathrm{D}_{3}$ in colon cancer. J Steroid Biochem and Molec Biol 2007;103:763-767.

-13 Gonzalez-Sancho JM, Larriba MJ, Ordonez-Moran P, Palmer HG, Munoz A: Effects of 1alpha,25-dihydroxyvitamin $\mathrm{D}_{3}$ in human colon cancer cells. Anticancer Res 2006;26:2669-2881.

14 Tangpricha V, Spina C, Yao M, Chen TC, Wolfe MM, Holick MF: Vitamin D deficiency enhances the growth of MC26 colon cancer xenografts in Balb/C mice. J Nutr 2005;135:2350-2354.

15 Cross HS, Bises G, Lechner D, Manhardt T, Kallay E: The vitamin D endocrine system of the gut: its possible role in colorectal cancer prevention. J Steroid Biochem Molec Biol 2005;97:121-128.

16 Garland CF, Grant WB, Mohr SB, Gorham ED, Garland FC: What is the dose-response relationship between vitamin D and cancer risk? Nutr Rev 2007;65:S91-S95.

17 Gorham ED, Garland CF, Garland FC, Grant WB, Mohr SB, Lipkin M, Newmark HL, Giovannucci E, Wei M, Holick MF: Optimal vitamin D status for colorectal cancer prevention: a quantitative meta analysis. Am J Preventive Med 2007:32:210-216.

18 Rohan T: Epidemiological studies of vitamin D and breast cancer. Nutr Rev 2007;65:S80-S83.

19 Giovannucci E: Strengths and limitations of current epidemiologic studies: vitamin D as a modifier of colon and prostate cancer risk. Nutr Rev 2007;65:S77-S79.

20 Gandini S, Boniol M, Haukka J, Byrnes G, Cox B, Sneyd MJ, Mullie P, Autier P: Meta-analysis of observational studies of serum 25-hydroxyvitamin D levels and colorectal, breast and prostate cancer and colorectal adenoma. Int J Cancer 2010, Epub ahead of print.

21 IARC: Vitamin D and Cancer. IARC Working Group Reports, vol 5. Lyon, International Agency for Research on Cancer, 2008.

22 Tuohimaa P, Tenkanen L, Ahonen M, Summe S, Jellum E, Hallmans G, Stattin P, Harvei S, Hakulinen T, Luostarinen T, Dillner J, Lehtinen M, Hakama M: Both high and low levels of blood vitamin D are associated with a higher prostate cancer risk: a longitudinal, nested case-control study in the Nordic countries. Int J Cancer 2004;108:104-108.

-23 Ahn J, Peters U, Albanes D, Purdue MP, Abnet CC, Chatterjee N, Horst RL, Hollis BW, Huang W, Shikany JM, Hayes RB: Serum vitamin D concentration and prostate cancer risk: a nested case-control study. J Natl Cancer Inst 2008;100: 796-804.

24 Goodwin PJ, Ennis M, Pritchard KI, Koo J, Hood N: Prognostic effects of 25-hydroxyvitamin D levels in early breast cancer. J Clin Oncol 2009;27:3757-3763.

-25 Stolzenberg-Solomon RZ, Vieth R, Azad A, Pietinen P, Taylor PR, Virtamo J, Albanes D: A prospective nested casecontrol study of vitamin D status and pancreatic cancer risk in male smokers. Cancer Res 2006;66:10213-10219.

-26 Stolzenberg-Solomon RZ, Hayes RB, Horst RL, Anderson KE, Hollis BW, Silverman DT: Serum vitamin D and risk of pancreatic cancer in the prostate, lung, colorectal, and ovarian screening trial. Cancer Res 2009;69:1439-1447.

27 Chen W, Dawsey SM, Qiao Y-L, Mark SD, Dong Z-W, Taylor PR, Zhao P, Abnet CC: Prospective study of serum 25(OH)-vitamin D concentration and risk of oesophageal and gastric cancers. Br J Cancer 2007;97:123-128.

28 Abnet CC, Chen W, Dawsey SM, Wei W, Roth MJ, Liu B, Lu N, Taylor PR, Qiao Y: Serum 25(OH)-vitamin D concentration and risk of esophageal squamous dysplasia. Cancer Epidemiol Biomarkers Prev 2007;16:1889-1893.

29 Toner CD, Davis CD, Milner JA: The vitamin D and cancer conundrum: aiming at a moving target. J Am Diet Assoc 2010;110:1492-1500.

- 30 Raimondi S, Johansson H, Maisonneuve P, Gandini S: Review and meta-analysis on vitamin D receptor polymorphisms and cancer risk. Carcinogenesis 2009;30:1170-1180.

-31 Rukin NJ, Strange RC: What are the frequency, distribution and functional effects of vitamin D receptor polymorphisms as related to cancer risk? Nutr Rev 2007;65:S96-S101.

-32 Uitterlinden SG, Fang Y, van Meurs JB, Pols HA, van Leeuwen JP: Genetics and biology of vitamin D receptor polymorphism. Gene 2004;338:143-156.

-33 Zmuda JM, Cauley JA, Ferell RE: Molecular epidemiology of vitamin D receptor gene variants. Epidemiol Rev 2000; 22:203-217.

- 34 Whitfield GK, Remus LS, Jurutka PW, Zitzer H, Oza AK, Haussler CA, Galligan MA, Thatcher ML, Encinas Doninguez C, Haussler MR: Functionally relevant polymorphisms in the human nuclear vitamin D receptor gene. Mol Cell Endocrinol 2001;177:145-159.

- 35 Jurutka PW, Remus LS, Whitfield GK, Thompson PD, Hsieh JC, Zitzer H, Tavakkoli P, Galligan MA, Dang HT, Haussler CA, Haussler MR: The polymorphic N-terminus in human vitamin D receptor isoforms influences transcriptional activity by modulating interactions with transcription factor IIB. Mol Endocrinol 2000;14:401-420. 


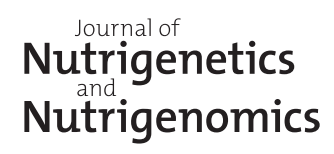

J Nutrigenet Nutrigenomics 2011;4:1-11

\begin{tabular}{l|l} 
DOI: $10.1159 / 000324175$ & ( 2011 S. Karger AG, Base
\end{tabular}

Published online: March 23, 2011

ention
$>36$

BJ, Plrich CM, Hsu L, Duggan D), Benitez DS, White E, Slattery ML, Farin FM, Makar KW, Carlson CS, Caan B), Potter JD, Peters U: Vitamin D re
Biomarkers Prev 2009; 18:2540-2548.

-42 Engelman CD, Fingerlin TE, Langefeld CD, Hicks PJ, Rich SS, Wagenknecht LE, Bowden DW, Norris JM: Genetic and environmental determines of 25-hydroxyvitamin D levels in Hispanic and African Americans. J Clin Endocrinol Metab 2008;93:3381-3388.

-43 Lauridsen AL, Vestergaard P, Hermann AP, Brot C, Heickendorff L: Plasma concentrations of 25-hydroxyvitamin D and 1,25-dihydoxy-vitamin D are related to the phenotype of $\mathrm{Gc}$ (vitamin D-binding protein): a cross sectional study on 595 postmenopausal women. Calcif Tissue Int 2005;77:15-22.

44 Ahn J, Yu K, Stolzenberg-Solomon R, Simon KC, McCullough ML, Gallicchio L, Jacobs EJ, Ascherio A, Helzlsouer K, Jacobs KB, Li Q, Weinstein SJ, Purdue M, Virtamo J, Horst R, Wheeler W, Chanock S, Hunter DJ, Hayes RB, Kraft P, Albanes D: Genome-wide association study of circulating vitamin D levels. Human Molecular Genet 1010;19:27392745.

45 Fleet J: What have genomic and proteomic approaches told us about vitamin D and cancer? Nutr Rev 2007;65:S127S130.

-46 Kriebitzsch C, Verlinden L, Eelen G, Tan BK, Camp MV, Bouillon R, Verstuyf A: The impact of 1,25(OH) ${ }_{2} \mathrm{D}_{3}$ and its structural analogs on gene expression in cancer cells-a microarray approach. Anticancer Res 2009;29:3471-3484.

-47 Wang QM, Jones JB, Studzinski GP: Cyclin-dependent kinase inhibitor p27 as a mediator of the G1-S phase block induced by 1,25-dihydroxyvitamin $\mathrm{D}_{3}$ in HL-60 cells. Cancer Res 1996;56:264-267.

48 Zhang X, Li P, Bao J, Nicosia SV, Wang H, Enkemann SA, Bai W: Suppression of death receptor-mediated apoptosis by 1,25-dihydroxyvitamin $\mathrm{D}_{3}$ revealed by microarray analysis. J Boil Chem 2005;280:35458-35468.

49 Townsend K, Trevino V, Falciani F, Stewart PM, Hewison M, Campbell MJ: Identification of VDR-responsive gene signatures in breast cancer cells. Oncology 2006;71:111-123.

50 Liu M, Lee MH, Cohen M, Bommakanti M, Freedman LP: Transcription of the Cdk inhibitor p21 by vitamin D leads to the induced differentiation of the myelomonocytic cell line U937. Genes Dev 1996;10:142-153.

51 Moffatt KA, Johannes WU, Hedlund TE, Miller GJ: Growth inhibitory effects of 1 alpha, 25-dihydroxyviatim D(3) are mediated by increased levels of p21 in the prostatic carcinoma cell line ALVA-31. Cancer Res 2004;64:2143-2147.

-52 Zhuang SH, Burnstein KL: Antiproliferative effect of 1 alpha,25-dihydroxyviatmin D3 in human prostate cancer cell line LNCaP involved reduction of cyclin-dependent kinase 2 activity and persistent G1 accumulation. Endocrinology 1998;139:1197-1207.

53 Boyle BJ, Zhao XY, Cohen P, Feldman D: Insulin-like growth factor binding protein-3 mediates 1,25-dihydroxyviatimin D growth inhibition in the LNCaP prostate cancer cell line through p21/WAF1. J Urol 2001;165:1319-1324.

54 Feldman D, Krishnan A, Moreno J, Swami S, Peehl DM, Srinivas S: Vitamin D inhibition of the prostaglandin pathway as therapy for prostate cancer. Nutr Rev 2007;65:S113-S115.

55 Vaisanen S, Dunlop TW, Sinkkonen L, Frank C, Carlberg C: Spatio-temporal activation of chromatin on the human CYP24 gene promoter in the presence of 1(,25-dihydroxyvitamin $\mathrm{D}_{3}$. J Mol Biol 2005;350:65-77.

56 Turunen MM, Dunlop TW, Carlberg C, Vaisanen S: Selective use of multiple vitamin D response elements underlies the 1(,25-dihydroxyvitamin $\mathrm{D}_{3}$-mediated negative regulation of the human CYP27B1 gene. Nucleic Acid Res 2007;35: 2734-2747.

57 Sinkkonen L, Malinen M, Saavalainen K, Vaisanen S, Carlberg C: Regulation of the human cyclin C gene via multiple vitamin $\mathrm{D}_{3}$-responsive regions in its promoter. Nucleic Acids Res 2005;33:2440-2451.

-58 Saramaki A, Banwell CM, Campbell MJ, Carlberg C: Regulation of the human $p 21^{(\text {wafl/cip1) }}$ gene promoter via multiple binding sites for $\mathrm{p} 53$ and the vitamin $\mathrm{D}_{3}$ receptor. Nucleic Acid Res 2006;34:543-554.

59 Carlberg C, Seuter S: A genomic perspective on vitamin D signaling. Anticancer Res 2009;29:3485-3494.

60 Zella LA, Kim S, Shevde NK, Pike JW: Enhances located within two introns of the vitamin D receptor gene mediate transcriptional autoregulation by 1,25-dihydroxyvitamin $\mathrm{D}_{3}$. Mol Endocrinol 2006;20:1231-1247.

61 Meyer MB, Watanuki M, Kim S, Shevde NK, Pike JW: the human transient receptor potential vanilloid type 6 distal promoter contains multiple vitamin $\mathrm{D}$ receptor binding sites that mediate activation by 1,25 -dihydroxyvitamin $\mathrm{D}_{3}$ in intestinal cells. Mol Endocrinol 2006;20:1447-1461.

62 Fretz JA, Zella LA, Kim S, Shevde NK, Pike JW: 1,25-Dihydroxyvitamin $\mathrm{D}_{3}$ induces expression of the Wnt signaling co-regulator LRP5 via regulatory elements located significantly downstream of the gene's transcriptional start site. J Ster Biochem Molec Biol 2007;103:440-445. 


\section{Journal of \\ Nutrigenetics \\ Nutrigenomics}

\begin{tabular}{l|l}
\hline J Nutrigenet Nutrigenomics 2011;4:1-11 \\
\hline DOI: 10.1159/000324175 & $\begin{array}{l}\text { @ 2011 S. Karger AG, Basel } \\
\text { www.karger.com/jnn }\end{array}$ \\
Published online: March 23, 2011 &
\end{tabular}

Davis et al.: Nutrigenomics, Vitamin D and Cancer Prevention
-63 sion by 1,25-dihydroxyvitamin $\mathrm{D}_{3}$ is mediated through multiple long range enhancers. Mol Cell Boil 2006;26:64696486.

64 Stambolsky P, Tabach Y, Fontemaggi G, Weisz L, Maor-Aloni r, Siegfried Z, Shiff I, Kogan I, Shay M, Kalo E, Blandino G, Simon I, Oren M, Rotter V: Modulation of the vitamin D3 response by cancer associated mutant p53. Cancer Cell 2010;17:273-285.

65 Mohri T, Nakajima M, Takagi S, Komagata S, Yokoi T: MicroRNA regulates human vitamin D receptor. Int J Cancer 2009;125:1328-1333.

66 Komagata S, Nakajima M, Takagi S, Mohri T, Tanija T, Yokoi T: Human CYP24 catalyzing the inactivation of calcitriol is post-transcriptional regulation by miR-125b. Mol Pharmacol 2009;76:702-709.

67 Chen TC, Wang L, Whitlatch LW, Flanagan JN, Holick MF: Prostatic 25-hydroxyvitamin D-1alpha-hydroxylase and its implication in prostate cancer. J Cell Biochem 2003;88:315-322.

68 Hsu JY, Feldman D, McNeal JE, Peehl DM: Reduced 1alpha-hydroxylase activity in human prostate cancer cells correlates with decreased susceptibility to 25-hydroxyvitamin $\mathrm{D}_{3}$-induced growth inhibition. Cancer Res 2001;61:28522856.

Weigel NL: Interactions between vitamin D and androgen receptor signaling in prostate cancer cells. Nutr Rev 2007; 65:S116-S117.

70 Chen TC, Wang L, Whitlatch LW, Flanagan JN, Holick MF: Prostatic 25-hydroxyviatim D-1-(-hydroxylase and its implication in prostate cancer. J Cell Biochem 2003;88:315-322.

-71 Friedrich M, Diesing D, Cordes T, Fischer D, Becker S, Chen TC, Flanagan JN, Tangpricha V, Gherson I, Holick MF, Reichrath J: Analysis of the 25-hydroxyvitamin $\mathrm{D}_{3}$-1-alpha-hydroxylase in normal and malignant breast tissue. Anticancer Res 2006;26:2615-2620.

72 Matusiak D, Murillo G, Carroll RE, Mehta RG, Benya RV: Expression of vitamin D receptor and 25-hydroxyvitamin D3-1\{alpha\}-hydroxylase in normal and malignant human colon. Cancer Epidemiol Biomarkers Prev 2005;14:23702376 .

$>73$ Albertson DG, Ylstra B, Segraves R, Collins C, Dairkee SH, Kowbel D, Kuo WL, Gray JW, Pinkel D: Quantitative mapping of amplicon structure by array CGH identifies CYP24 as a candidate oncogene. Nat Genet 2000;25:144-146.

74 Anderson MG, Nakane M, Ruan X, Kroeger PE, Wu-Wong JR: Expression of VDE and CYP24A1 mRNA in human tumors. Cancer Chemother Pharmacol 2006;57:234-240.

75 Matusiak D, Benya RV: CYP27A1 and CYP24 expression as a function of malignant transformation in the colon. J Histochem Cytochem 2007;55:1257-1264.

76 Bikle DD, Rasmussen $\mathrm{H}$ : The ionic control of 1,25-dihydroxyvitamin $\mathrm{D}_{3}$ production in isolated chick renal tubules. I Clin Invest 1975;55:292-298.

-77 Cross HS, Lipkin M, Kállay E: Nutrients regulate the colonic vitamin D system in mice: relevance for human colon malignancy. J Nutr 2006;136:561-564.

78 Cross HS, Kallay E: Regulation of the colonic vitamin D system for prevention of tumor progression: an update. Future Oncol 2009;5:493-507.

79 Cross H: Extrarenal vitamin D hydroxylase expression and activity in normal and malignant cells. Nutr Rev 2007; 65:S108-S112.

80 Rao A, Woodruff RD, Wade WN, Kute TE, Cramer SD: Genistein and vitamin D synergistically inhibit human prostatic epithelial cell growth. J Nutr 2002;132:3191-3194

-81 Rao A, Coan A, Welsh J, Barclay WW, Koumenis C, Cramer SD: Vitamin D receptor and p21/WAF1 are targets of genistein and 1,25-dihydroxyvitamin $\mathrm{D}_{3}$ in human prostate cancer cells. Cancer Res 2004;64:2143-2147.

82 Mawer EB, Backhouse J, Holman CA, Lumb GA, Standbury SW: The distribution and storage of vitamin D and its metabolites in human tissues. Clin Sci 1972;43:413-431.

83 Liel Y, Ulmer E, Shary J, Hollis BW, Bell NH: Low circulating vitamin D in obesity. Calcific Tissue Int 1988;43:199_ 201.

84 Bell NH, Epstein S, Greene A, Shary J, Oexmann MJ, Shaw S: Evidence of alteration in the vitamin D-endocrine system in obese subjects. J Clin Invest 1985;76:370-373.

85 Wortsman J, Matsuoka LY, Chen TC, Lu Z, Holick MF: Decreased bioavailability of vitamin D in obesity. Am J Clin Nutr 2000;72:690-693

86 Rosensterich SJ, Rich C, Volwiler W: Deposition in and release of vitamin $\mathrm{D}_{3}$ from body fat: evidence for a storage site in the rat. J Clin Invest 1971;50:679-687.

-87 Brouwer DA, van Beek J, Ferwerda H, Brugman AM, van der Klis FR, van der Heiden HJ, Muskiet FA: Rat adipose tissue rapidly accumulates and slowly releases an orally-administered high vitamin D dose. Br J Nutr 1998;79:527-532.

88 Lagunova Z, Porojinicu AC, Grant WB, Bruland O, Moan JE: Obesity and increased risk of cancer: does decrease of serum 25-hydroxyvitamin D level with increasing body mass index explain some of the association? Mol Nutr Food Res 2010;54:1-7.

89 Teegarden D, White KM, Lyle RM, Zemel MB, Van Loan MD, Matkovic V, Craig BA, Schoeller DA: Calcium and dairy product modulation of lipid utilization and energy expenditure. Obesity 2008;16:1566-1572.

-90 Ortega RM, Aparicio A, Rodriguez-Rodriguez E, Bermejo LM, Perea JM, López-Sobaler AM, Ruiz-Roso B, Andrés P: Preliminary data about the influence of vitamin D status on the loss of body fat in young overweight/obese women following two types of hypocaloric diet. Br J Nutr 2008;100:269-272.

91 Looker AC: Do body fat and exercise modulate vitamin D status? Nutr Rev 2007;65:S124-S126. 